\title{
EVALUASI EFEKTIVITAS FRAKSI EKSTRAK JARAK TINTIR DAN TEMBELEKAN UNTUK MENGENDALIKAN PENYAKIT ANTRAKNOSA PADA CABAI MERAH
}

\section{THE EFFECTIVITY EVALUATION OF EXTRACT JARAK TINTIR FRACTION AND TEMBELUKAN FOR CONTROL ANTRAKNOSA DISEASE IN RED CHILI}

\author{
Made Suwastini, Efri, Ivayani, dan Radix Suharjo \\ Jurusan Agroteknologi, Fakultas Pertanian, Universitas Lampung \\ Jalan Prof. Dr. Soemantri Brojonegoro No.1 Bandar Lampung 35145
}

\begin{abstract}
Anthracnose disease is an important disease in chili plants caused by the fungus Colletotrichum capsici and C. Gloeosporiodes. One of alternative control that can be applied to limit the use of synthetic pesticides and also friendly for environment is application of fungicides that based on plant leaf extracts. The aim of this study was to evaluate the ability of vegetable fungicides from Jatropha multifida extract and Lantana camara to control anthracnose in chilli fruit.The study was conducted in the experimental field of Hajimena Natar Village, South Lampung from September to December 2017. The treatments were designed in a randomized block design (RBD), with four treatments and six replications. The homogeneity of the data was tested by the Bartlet test. the data that obtained were processed by variance and the comparison of the mean values between treatments was tested with the smallest significant difference test (LSD) at 5\% significance level. The results showed that fraction of Jarak tintir extract and fraction of tembelekan extract have significantly affected in harvest 1 and 2 towards to suppress the occurrence of anthracnose disease, and also significantly affected the suppression of severity and storage only at second week of harvest.
\end{abstract}

Keywords : Anthracnose, Colletotrichum capsici, fraction extract

\begin{abstract}
ABSTRAK
Penyakit antraknosa merupakan penyakit penting pada tanaman cabai yang disebabkan oleh jamur Colletotrichum capsici dan C. gloeosporiodes. Salah satu alternatif pengendalian yang dapat diterapkan untuk membatasi penggunaan pestisida sintetik dan juga ramah lingkungan adalah penggunaan fungisida nabati yang berbahan dasar ekstrak daun tumbuhan.Penelitian ini bertujuan untuk mengevaluasi kemampuan fungisida nabati fraksi ekstrak jarak tintir (Jatropha multifida)dan tembelekan (Lantana camara) untuk mengendalikan penyakit antraknosa pada buah cabai.Penelitian dilakukan di lahan percobaan Desa Hajimena Natar, Lampung Selatan dari bulan September sampai dengan Desember 2017. Perlakuan disusun dalam rancangan acak kelompok(RAK), dengan empat perlakuan dan enam ulangan.Kehomogenan data diuji dengan uji Bartlet. Data yang diperoleh
\end{abstract}


diolah dengansidik ragam dan perbandingan nilai tengah antar perlakuan diuji dengan uji bedanyata terkecil (BNT) pada tarafnyata 5\%. Hasil penelitian menunjukkan fraksi ekstrak jarak tintir dan fraksi ekstrak tembelekan berpengaruh nyata pada panen 1 dan 2 terhadap penekanan keterjadian penyakit antraknosa, serta berpengaruh nyata terhadap penekanan keparahan dan penyimpanan hanya pada minggu panen 2.

Kata kunci: Antraknosa, Colletotrichum capsici, fraksi ekstrak

\section{PENDAHULUAN}

Kebutuhan cabai di Indonesia dari tahun ke tahun terus mengalami peningkatan. Namun begitu, hingga saat ini produksi cabai di Indonesia masih belum dapat memenuhi kebutuhan masyarakat secara luas. Hal tersebut disebabkan karena produksi yang fluktuatif dengan produktivitas yang tergolong rendah.Rendahnya produktivitas cabai tersebut didugaadanya permasalahan hama dan penyakit tanaman (Warisno dan Dahana, 2010). Salah satu penyakit penting pada tanaman cabai merah yaitu penyakit antraknosa. Piay dkk. (2010), menyebutkan bahwa penyakit antraknosa disebabkan oleh jamur Colletotrichum capsici dan C. gloeosporiodes.

Selama ini, cara pengendalian penyakit pada tanaman cabai yang diterapkan yaitu dengan menggunakan fungisida sintetik. Penggunaan fungisida sintetik dapat menimbulkan beberapa masalah diantaranya meningkatnya resistensi jamur Colletotrichum terhadap fungisida. Pemanfaatan pestisida nabati merupakan salah satu alternatif yang dapat diterapkan untuk permasalahan di atas dan juga ramah lingkungan. Hasil penelitian yang dilakukan oleh Yuliandari (2017), ekstrak tanaman tembelekan dapat menekan intensitas penyakit antraknosa pada buah cabai. Agnita dkk. (2014) melaporkan secara in-vitro,

\section{BAHAN DAN METODE}

Penelitian ini disusun dalam rancangan acak kelompok (RAK), terdapat empat perlakuan dan enam ulangan. Kehomogenan data diuji dengan uji Bartlet. Data yang diperoleh diolah dengansidik ragam dan perbandingan nilai tengah antar perlakuan diuji dengan uji bedanyata terkecil (BNT) pada taraf nyata 5\%.Keempat perlakuan tersebut adalah kontrol (P0), fraksi ekstrak jarak tintir(P1), fraksi ekstrak tembelekan(P2), dan fungisida berbahan aktif propineb (P3).

\section{Pembuatan Fraksi Ekstrak Daun Tembelekan}

\section{dan Daun Jarak Tintir}

Pembuatan fraksi ekstrak tembelekan dan jarak tintir dibuat dengan menggunakan blender dan juga alat fraksinasi sederhana. Masing-masing $200 \mathrm{~g}$ daun tanaman dicuci hingga bersih, dikering anginkan, dan selanjutnya dihaluskan dengan menggunakan blender yang diberi air hingga volume menjadi 1000 $\mathrm{ml}$ air. Daun tanaman yang telah diblender disaring dan dimasukkan ke dalam alat fraksinasi. Hasil dari fraksinasi ditampung di dalam nampan. Masing-masing fraksi ekstrak dikeringkan/diuapkan dengan menggunakan rotary evaporator atau secara manual dengan meletakkan di tempat terbuka, sehingga didapatkan ekstrak kering. Ekstrak kering dijadikan 
sebagai bahan untuk perlakuan.

\section{Penyiapan Isolat $C$. Capsici sebagai Inokulum}

Inokulum C. capsici didapatkan dengan memperbanyak pada buah cabai dengan mencampurkan buah cabai yang segar dengan buah cabai yang sakit (terinfeksi C. capsici). Pencampuran dilakukan agar buah cabai yang sehat tertular oleh buah cabai yang sakit. Suspensi inokulum dibuat dengan cara menambahkan 21 air dalam 500 gram cabai yang terinfeksi, kemudian diaduk agar menjadi larutan dan disaring menggunakan saringan. $1 \mathrm{~kg}$ cabai yang terinfeksi diperoleh suspensi sebanyak 41. Setelah itu, dilakukan penghitungan kerapatan spora menggunakan haemocytometer. Kerapatan spora jamur C. capsici yang diaplikasikan yaitu $2.9 \times 10^{6} \mathrm{spora} / \mathrm{ml}$.

\section{Aplikasi Perlakuan Fraksi Ekstrak Jarak Tintir}

\section{dan Tembelekan}

Aplikasi ekstrak tanaman dilakukan pada tanaman cabai yang telah berbuah dengan cara penyemprotan menggunakan handsprayer. Aplikasi pertama ekstrak tanaman dilakukan 60 menit sebelum inokulasi C. capsici. Aplikasi perlakuan ekstrak tanaman dilakukan 3 kali setiap minggu. Perlakuan fraksi ekstrak tanaman diaplikasikan dengan menggunakan konsentrasi masing-masing 5000 ppm (5g/l) ditambahkan deterjen sebanyak. Penyemprotan dilakukan secara merata pada semua bagian tanaman selama 5 detik sebanyak $18 \mathrm{ml} /$ tanaman.

\section{Inokulasi}

Inokulasi biakan C. capsici dilakukan dengan cara menyemprotkan pada tanaman cabai yang telah berbuah, dimana biakan C. capsici sebelumnya telah disuspensikan. Suspensi C. capsici disemprotkan pada tanaman cabai setelah 60 menit aplikasi ekstrak tanaman uji. Inokulasi dilakukan pada saat tanaman cabai berbuah dengan cara penyemprotan secara merata dengan sprayer pada seluruh bagian tanaman saat sore hari. Penyemprotan dilakukan secara merata selama 5 detik, sebelumnya telah dilakukan kalibrasi dan diperoleh volume $18 \mathrm{ml} /$ tanaman.

\section{Pengamatan}

Pengamatan dilakukan terhadap intensitas penyakit antraknosa dengan frekuensi satu minggu sekali. Intensitas penyakit terdiri dari keterjadian penyakit dan keparahan penyakit.

\section{Keterjadian Penyakit}

Keterjadian penyakit dihitung dengan cara menghitung jumlah buah cabai yang bergejala pada masing-masing tanaman dengan rumus (Natawigena,1993) sebagai berikut :

$$
\mathrm{TP}=\frac{\mathrm{n}}{N} \times 100 \%
$$

Keterangan :

$\mathrm{TP}=$ Keterjadian Penyakit $(\%)$

$\mathrm{n}=$ Jumlah buah yang terinfeksi (bergejala) per tanaman

$\mathrm{N}=$ Jumlah total buah yang diamati per tanaman

\section{Keparahan Penyakit}

Keparahan penyakit adalah luasnya permukaan buah cabai yang menunjukkan gejala penyakit. Keparahan penyakit juga dapat diartikan sebagai bagian dari tanaman yang terserang penyakit atau daerah penyakit dari tanaman sampel. Keparahan penyakit dapat 
dihitung dengan rumus (Natawigena,1993) sebagai berikut:

Keterangan :

$\mathrm{KP}=$ Keparahan penyakit (\%)

$\mathrm{N}=$ Jumlah buah yang diamati setiap tanaman

$\mathrm{n}=$ Banyaknya buah dalam setiap kategori serangan

$\mathrm{v}=$ Nilai numerik untuk tiap kategori serangan

$\mathrm{V}=$ Nilai skor tertinggi

\section{Masa Simpan Buah}

Pengamatan perkembangan penyakit setelah panen (masa simpan buah) dilakukan terhadap buah cabai selama 6 hari dan dilakukan setiap hari. Buah cabai yang diamati yaitu buah cabai yang telah bergejala dengan persentase keparahan awal sebesar 1\%-40\%. Buah cabai disimpan dalam plastik putih yang berukuran $1 \mathrm{~kg}$ dan ujungnya diikat mengunakan karet dan diletakkan dalam nampan, kemudian diletakkan dalam ruangan suhu kamar dengan kondisi cahaya redup.
Pengamatan dilakukan untuk melihat lamanya kemampuan fraksi ekstrak tanaman dalam menekan pertumbuhan C. capsici setelah dilakukan pemanenan berdasarkan keparahan penyakit.

\section{HASIL DAN PEMBAHASAN}

\section{Hasil Pengamatan}

Berdasarkan hasil pengamatan gejala, penyakit antraknosa mulai tampak pada 3 sampai 4 hari setelah inokulasi (hsi). Gejala tersebut berupa bercak berbentuk lonjong dengan warna coklat kehitaman. Kelompok seta dan konidium jamur terdapatpada tengah bercak yang terlihat seperti kumpulan titiktitik hitam (Gambar 1).

\section{Keterjadian Penyakit Antraknosa}

Hasil analisis data pada panen 1 menunjukkan bahwa perlakuan berpengaruh nyata dalam menekan intensitas penyakit antraknosa pada buah cabai.Keterjadian penyakit dengan perlakuan fungisida nabati berbeda nyata dengan perlakuan kontrol, tetapi
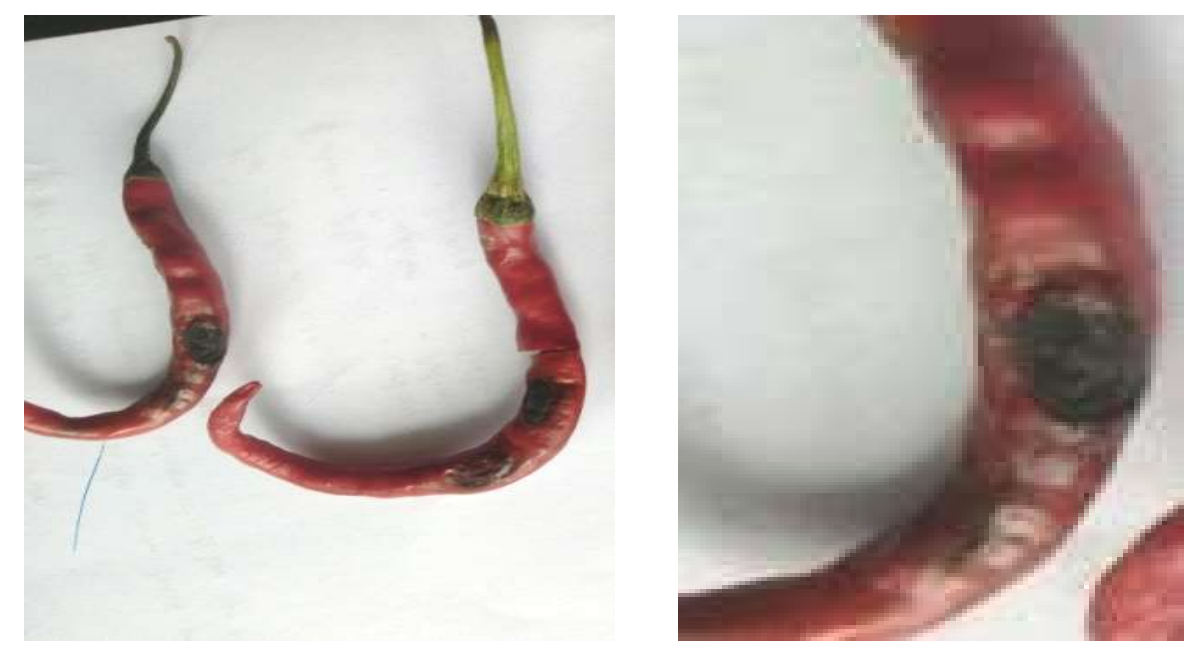

Gambar 1. Gejala penyakit antraknosa pada buah cabai yang diamati 
perlakuan P1 dan P2 tidak berbeda nyata. Penekanan intensitas penyakit tertinggi terdapat pada perlakuan aplikasi propineb dengan keterjadian penyakit hanya sebesar 5,96\%.

Selanjutnya pestisida nabati jarak tintir dan tembelekan berpengaruh terhadap penekanan intensitas penyakit antraknosa keterjadian penyakit berturut-turut sebesar $14,70 \%$ dan $13,05 \%$. Keterjadian penyakit tertinggi terdapat pada perlakuan kontrol yaitu sebesar $25,64 \%$. Hasil analisis data pada panen 2 menunjukkan hasil yang sama dengan hasil analisis data pada panen 1. Penekanan intensitas penyakit antraknosa tertinggi terdapat pada perlakuan aplikasi propineb yaitu keterjadian penyakit sebesar $0,00 \%$, pestisida nabati jarak tintir dan tembelekan berturut-turut sebesar 3,33\% dan 1,78\%. Keterjadian penyakit tertinggi terdapat pada perlakuan kontrol yaitu sebesar 7,22\%. Akan tetapi pada pengamatan panen 3 perlakuan tidak berpengaruh nyata terhadap keterjadian penyakit antraknosa (Tabel 1).

\section{Keparahan Penyakit Antraknosa}

Hasil analisis data keparahan penyakit antraknosa padapanen 1 menunjukkan bahwa perlakuan tidak berpengaruh nyata terhadap penekanan keparahan penyakit antraknosa. Hasil analisis data padapanen 2 menunjukkan bahwa

Tabel 1. Keterjadian penyakit antraknosa buah cabai pada berbagai perlakuan.

\begin{tabular}{cccc}
\hline \multirow{2}{*}{ Perlakuan } & \multicolumn{3}{c}{ Keterjadian Penyakit (\%) } \\
\cline { 2 - 4 } & Panen 1 & Panen 2 & Panen 3 \\
P0 & $25,64 \mathrm{c}$ & $7,22(1,74) \mathrm{c}$ & $7,88 \mathrm{a}$ \\
P1 & $14,70 \mathrm{~b}$ & $3,33(1,42) \mathrm{b}$ & $5,84 \mathrm{a}$ \\
P2 & $13,05 \mathrm{~b}$ & $1,78(1,34) \mathrm{b}$ & $3,51 \mathrm{a}$ \\
P3 & $5,96 \mathrm{a}$ & $0,00(1,10) \mathrm{a}$ & $4,17 \mathrm{a}$ \\
\hline BNT 5\% & 5.23 & 0,13 & \\
\hline Keterangan : Angka yang diikuti dengan huruf yang sama pada kolom yang sama menunjukkan tidak berbeda \\
nyata menurut uji bnt 5\%, angka dalam kurung merupakan hasil transformasi akar x $+0,5$, \\
P0 = kontrol, P1 = fraksi ekstrak daun jarak tintir, P2 = fraksi ekstrak tembelekan, P3 = propineb, \\
msi (minggu setelah inokulasi).
\end{tabular}

Tabel 2. Keparahan penyakit antraknosa buah cabai pada berbagai perlakuan

\begin{tabular}{cccc}
\hline \multirow{2}{*}{ Perlakuan } & \multicolumn{3}{c}{ Keparahan Penyakit (\%) } \\
\cline { 2 - 4 } & Panen 1 & Panen 2 & Panen 3 \\
\hline P0 & $7,98 \mathrm{a}$ & $1,56(1,60) \mathrm{c}$ & $1,58 \mathrm{a}$ \\
P1 & $6,52 \mathrm{a}$ & $1,20(1,53) \mathrm{b}$ & $1,30 \mathrm{a}$ \\
P2 & $3,27 \mathrm{a}$ & $0,36(1,44) \mathrm{a}$ & $0,89 \mathrm{a}$ \\
P3 & $2,23 \mathrm{a}$ & $0,00(1,41) \mathrm{a}$ & $0,83 \mathrm{a}$ \\
\hline BNT 5\% & & 0,06 & \\
\hline
\end{tabular}

Keterangan : Angka yang diikuti dengan huruf yang sama pada kolom yang sama menunjukkan tidak berbeda nyata menurut uji bnt $5 \%$, angka dalam kurung merupakan hasil transformasi akar $\mathrm{x}+0,5$, $\mathrm{P} 0=$ kontrol, $\mathrm{P} 1=$ fraksi ekstrak daun jarak tintir, $\mathrm{P} 2=$ fraksi ekstrak tembelekan, $\mathrm{P} 3=$ propineb, msi (minggu setelah inokulasi). 
Tabel 3. Pengaruh masa simpan terhadap peningkatan keparahan penyakit pada semua perlakuan

\begin{tabular}{cccc}
\hline \multirow{2}{*}{ Perlakuan } & \multicolumn{3}{c}{ Keparahan Penyakit (\%) } \\
\cline { 2 - 4 } & $1 \mathrm{msi}$ & $2 \mathrm{msi}$ & $3 \mathrm{msi}$ \\
\hline P0 & $11,84 \mathrm{a}$ & $2,89 \mathrm{c}$ & $3,15 \mathrm{a}$ \\
P1 & $8,39 \mathrm{a}$ & $1,16 \mathrm{~b}$ & $2,21 \mathrm{a}$ \\
P2 & $5,76 \mathrm{a}$ & $0,63 \mathrm{~b}$ & $1,23 \mathrm{a}$ \\
P3 & $2,74 \mathrm{a}$ & $0,00 \mathrm{a}$ & $1,67 \mathrm{a}$ \\
\hline BNT 5\% & & 0.58 & \\
\hline
\end{tabular}

Keterangan : Angka yang diikuti dengan huruf yang sama pada kolom yang sama menunjukkan tidak berbeda nyata menurut uji bnt 5\%, P0 = control, $\mathrm{P} 1=$ fraksi ekstrak daun jarak tintir, $\mathrm{P} 2=$ fraksi ekstrak tembelekan, $\mathrm{P} 3=$ propineb.

perlakuan berpengaruh nyata terhadap penekanan keparahan penyakit antraknosa. Keparahan penyakit antraknosa pada perlakuan P1, P2, dan P3 berbeda nyata dengan tanpa perlakuan, dimana perlakuan P2 dan P3 pengaruhnya tidak berbeda nyata. Penekanan keparahan penyakit tertinggi terdapat pada perlakuan aplikasi propineb yaitu keparahan penyakit sebesar $0,00 \%$. perlakuan pestisida nabati jarak tintir dan tembelekan berpengaruh terhadap penekanan keparahan penyakit antraknosa berturut-turut yaitu sebesar $1,20 \%$ dan $0,36 \%$. Keparahan penyakit tertinggi terdapat pada perlakuan kontrol yaitu sebesar 1,56\%. Akan tetapi hasil pengamatan pada panen 3 menunjukkan bahwa perlakuan tidak berpengaruh nyata terhadap penekaan keparahan penyakit antraknosa (Tabel 2).

Tingkat Keparahan Penyakit Pada Buah Selama

\section{Masa Simpan}

Hasil analisis datapada panen 1 menunjukkan bawa perlakuan tidak berpengaruh nyata terhadap penekanan keparahan penyakit antraknosa pada buah cabai selama peyimpanan sampai hari keenam Hasil analisis data pada panen 2 menunjukkan bahwa keparahan penyakit dengan perlakuan fungisida nabati berbeda nyata dengan perlakuan kontrol, tetapi perlakuan P1 dan P2 tidak berbeda nyata. Penekanan keparahan penyakit tertinggi terdapat pada perlakuan propineb yaitu keparahan penyakit sebesar $0,00 \%$. selanjutnya perlakuan pestisida nabati jarak tintir dan tembelekan berpengaruh terhadap penekanan keparahan penyakit antraknosa berturut-turut sebesar $1,16 \%$ dan $0,63 \%$. keparaha penyakit tertinggi pada perlakuan kontrol yaitu sebesar 2,89\%. Hasil analisis data pada panen 3 menunjukkan perlakuan tidak berpengaruh nyata dalam penekanan keparahan penyakit selama penyimpanan sampai hari keenam (Tabel 3).

\section{Pembahasan}

Hasil analisis data keterjadian penyakit panen 1 dan 2 menunjukkan perlakuan berbeda nyata, akan tetapi pada panen 3 tidak berbeda nyata. Hasil analisis data keparahan dan penyimpanan pada panen 2 berbeda nyata, akan tetapi pada panen 1 dan 3 tidak berbeda nyata. Pengaruh perlakuan yang tidak konsisten diduga adanya pengaruh faktor lingkungan. 
Faktor lingkungan yang paling berpengaruh yaitu suhu, kelembaban, dan curah hujan. Jamur penyebab penyakit antraknosa berkembang dengan sangat pesat bila kelembaban udara cukup tinggi yaitu bila lebih dari $80 \%$. Curah hujan tinggi akan mempercepat tanaman tumbuh dan bersifat sekulen sehingga tanaman rentan terserang patogen. Iklim pada minggu pertama aplikasi yaitu suhu rata-rata $28,7^{\circ} \mathrm{C}$, kelembaban rata-rata $81,5 \%$, dan curah hujan $20,8 \mathrm{~mm}$. Iklim pada minggu kedua aplikasi yaitu suhu rata-rata $29,12^{\circ} \mathrm{C}$, kelembaban rata-rata $77,8 \%$, dan curah hujan $1,4 \mathrm{~mm}$. Iklim pada minggu ketiga aplikasi yaitu suhu rata-rata $29,1^{\circ} \mathrm{C}$, kelembaban rata-rata $79,7 \%$, dan curah hujan 2,8 mm. Kelembaban dan curah hujan yang rendah menyebabkan intensitas penyakit rendah.

Menurut penelitian yang dilakukan Sila dan Sopialena (2016) aplikasi fungisida berbahan aktif propineb menunjukkan pengaruh yang nyata menekan intesitas penyakit pada tanaman cabai, dibandingkan dengan perlakuan Benlate, Manzate, Dithane M-45. Rata-rata intensitas penyakit tertinggi yaitu terdapat pada perlakuan $\mathrm{P} 0$ sebesar 7,55, sedangkan intensitas penyakit terendah yaitu pada perlakuan P1 sebesar 4,19 .

Senyawa flavonoid dapat menghambat pertumbuhan fungi dengan cara protein mikrotubulus dalam sel dan mengganggu fungsi mitosis gelendong (Siswandono dan Soekardjo, 2000). Senyawa alkaloid dapat menyebabkan kerusakan membrane sel dengan cara berikatan kuat dengan ergosterol membentuk lubang sehingga menyebabkan kebocoran membran sel.
Sugiyem (2015) melakukan penelitian mengenai pengaruh esktrak L.camara terhadap pertumbuhan dan sporulasi jamur C.capsicisecara in vitro. Hasil penelitian melaporkan bahwa aplikasi ekstrak L.camara menggunakan pelarut air mampu menghambat pertumbuhan dan sporulasi jamur $C$. capsicisecara in vitro. Menurut penelitian Kasim (2014) menyatakan bahwa pelarut air dilaporkan dapat melarutkan senyawa flavonoid dan saponin. Pelarut air juga dilaporkan mampu melarutkan senyawa alkaloid, tanin, dan fenol (Panda dkk., 2010). Berdasarkan hasil penelitian yang dilakukan oleh (Purmawati, 2008) kadar senyawa kimia yang terlarut pada ekstrak air gandarusa (Justicia gandarussa) yaitu rata-rata $68,56 \%$, sedangkan kadar senyawa kimia terlarut pada pelarut methanol yaitu rata-rata $47,62 \%$.

\section{KESIMPULAN}

Berdasarkan dari hasil penelitian yang telah dilakukan dapat disimpulkan bahwa pengaruh fraksi ekstrak jarak tintir dan fraksi ekstrak tembelekan berpengaruh nyata pada panen 1 dan 2 terhadap penekanan keterjadian penyakit antraknosa, serta berpengaruh nyata terhadap penekanan keparahan dan penyimpanan hanya pada minggu panen 2 . 


\section{DAFTAR PUSTAKA}

Agnita,P., Waluyo.J., dan Wahyuni, D.2014.Perbedaan daya hambat ekstrak dan rebusan daun jarak pagar (Jatropha curcas L.) terhadap pertumbuhan Candida albicans(Robin) Berkhout. Artikel Ilmiah Hasil Penelitian Mahasiswa Tahun 2014. Universitas Jember. Jawa Timur.

Kasim, M.M. 2014. Ekstraksi dan Fraksinasi Komponen Daun Tumbuhan JeringauSerta Pengujian EfekAntimakan Terhadap Serangga Kumbang Kepik. Skripsi.Universitas Negri Gorontalo. Gorontalo.

Natawigena, H. 1993. Dasar-Dasar Perlindungan Tanaman. Trigenda Karya. Bandung.

Panda, DS., Kumar KT., Nanda UN., dan Khuntia S. 2010. Evaluation of antibacterial, antifungal and anthelmintic activity of Morinda citrifolia L.(Noni). Int. J. PharmTech. Res. 2(2):10301032.

Piay, S., Tyasdjaja A., Ermawati dan Hantoro F. 2010. Budidaya dan Pasca Panen Cabai Merah(Capsicum annum L). BP3BTP. Ungaran.

Purmawati, M. 2008. Karakterisasi Estrak Air Daun Gandarusa (Justicia gandarussa Burm. F.) dan Pengaruh terhadap Kadar Asam Urat Plasma Tikus Putih Jantan yang diinduksi Kalium Oksalat. Skripsi. Universitas Indonesia.

Sila, S. dan Sopialena. 2016.Efektivitas beberapa fungisida terhadap perkembangan penyakit dan produksi tanaman cabai. Jurnal AGRIFOR. 15(1):119-120.
Siswandono dan Soekardjo, B. 2000. Kimia Medisinal, Edisi 2. Airlangga University Press. Surabaya.

Sugiyem, W. 2015. Pengaruh Tingkat Konsentrasi Ekstrak Tagetes erecta L. danLantana camara L. terhadap Pertumbuhan dan Sporulasi Colletotrichumcapsici Penyebab Penyakit Antraknosa pada Cabai Secara In Vitro. Skripsi.Fakultas Pertanian Universitas Lampung. Bandar Lampung.

Warisno dan Dahana. 2010. Peluang Usaha dan Budidaya Cabai. PT. Gramedia Pustaka Utama. Jakarta.

Yuliandari, M. 2017. Pengaruh Fraksi Ekstrak Lantana (Lantana camara)TerhadapIntensitas PenyakitAntraknosa(Colletotrichum capsici) Pada Tanaman Cabai Merah (Capsicum annum L.). Skripsi. Fakultas Pertanian Universitas Lampung. Bandar Lampung. 